\title{
Identification and expression of gonadotrophin hormones in gouramy (Osphronemous gouramy, Lacepède, 1801) under photoperiod manipulations
}

\author{
NORMAN ARIE PRAYOGO ${ }^{1, \bullet}$, ASRUL SAHRI SIREGAR ${ }^{1}$, PURNAMA SUKARDI ${ }^{1}$, YASUMASA BESSHO ${ }^{2}$ \\ ${ }^{1}$ Faculty of Fisheries and Marine Science, Universitas Jenderal Soedirman. Jl. Dr. Soeparno, Karangwangkal, Purwokerto Utara, Banyumas 53122, \\ Central Java, Indonesia. Tel.: +62-281-642360, Fax.: +62-281-7607433, "email: norman_s2biologi@yahoo.com \\ ${ }^{2}$ Division of Biological Science, Graduate Scholl of Science and Technology, Nara Institute Science and Technology. 8916-5 Takayama, Ikoma, Nara \\ 630-01-01, Japan
}

Manuscript received: 5 October 2019. Revision accepted: 9 March 2020.

\begin{abstract}
Prayogo NA, Siregar AS, Sukardi P, Bessho Y. 2020. Identification and expression of gonadotrophin hormones in gouramy (Osphronemoous gouramy, Lacepède, 1801) under photoperiod manipulations. Biodiversitas 21: 1365-1372. The environment influences fish reproduction. One of the influential environmental factors is photoperiod that regulates the production of hormones for gonad growth and development, gametogenesis, then the reproductive cycle. This research was conducted to determine the effect of photoperiod on the reproductive performance of gouramy with different photoperiod treatments. The design of this study was four photoperiod treatments consisting of 14L: 10D, 16L: 8D and 18L: 6D and controls. Fish samples were divided into 4 aquariums consisting of nine fish and repetition was conducted on each. Fish were kept under photoperiod treatment for 16 weeks. The observed variable was pituitary activity. Pituitary activity was evaluated by measuring the expression of FSH and LH genes using Real Time PCR. The results showed that gouramy had FSH and LH genes with $483 \mathrm{bp}$ and $506 \mathrm{bp}$. FSH and LH gene expression increased with long photoperiod exposure $(\mathrm{P}<0.05)$. These findings indicate that photoperiods regulate the reproduction of gouramy through the HPG axis and control the production of the hormone Gonadotropin.
\end{abstract}

Keywords: Gouramy, GtH, mRNA, gene expression, photoperiods, reproduction

\section{INTRODUCTION}

Maturation in fish controlled by internal and external factors (Prayogo et al. 2016b; Siregar and Prayogo 2018). Photoperiod regulated reproduction through the brain that integrates and conveys input from external and internal cues to the pituitary through melatonin (Prayogo et al. 2012). Melatonin inhibits the synthesis and secretion of the kisspeptin and gonadotrophin releasing hormone $(\mathrm{GnRH})$ (Shin et al. 2014). Gonadothropins releasing hormone will induce secretion of gonadotrophins $(\mathrm{GtHs})$ and then regulate the activities of the gonad, (Shin et al. 2014). Gonad produced ovarian hormone estradiol and progesterone that play an important role in maintaining and promoting the reproduction of gametes (Prayogo et al. 2016a). In salmonids, plasma FSH levels increase during spermatogenesis and vitellogenesis but decrease during sperm occurring in male, and late maturation and ovulation in females (Minniti et al. 2007). In comparison, LH levels are low during the early stages and increase in the final stages of sperm reproduction in males, and late maturation and ovulation in females (Miranda et al. 2008). Both of these GTH play a role in stimulating the production of estradiol-17B (E2), the hormone LH and the hormone FSH role in stimulating the steroid hormone, DHP $(17 \mathrm{a}, 20$ dihydroxy-pregnant-3-one) (Ulloa et al 1999; Veras et al. 2013). The gonadotrophins protein was heterodimer, consisting of unique beta subunit and common alpha subunit. The terms GtH-I and GtH-II were used before 2000s, while the following year the more commonly used terms were follicle-stimulating-hormone (FSH) and luteinizing hormone (LH). The FSH and $\mathrm{LH}$ gene is divided into two sub-units, namely the GtH-II gene subunit $\alpha$ and the GtH-II gene sub-unit $\beta$. The non-covalent association of two subunits $(\alpha$ and $\beta$ ) determines the formation and release of the bioactive dimer hormone (Lapthorn et al. 1994). The $\alpha$ subunit contains 92 amino acid residues with five disulfide bonds that contribute to tertiary structure formation. However, the $\beta$ subunit has a different amino acid sequence and carries specific information that will be expressed when it has been combined with the $\alpha$ subunit. Subunit $\beta$ in mammals contains 111 amino acid residues with six disulfide bonds (Zhang et al. 2015).

Photoperiod is one of the environmental factors that regulates egg-laying time in fish such as carp Cyprinus carpio (Moniruzzaman and Maitra 2012), goldfish, Carassius auratus (Shin et al. 2014), Nile tilapia Oreochromis nilaticus (Veras et al. 2013), Atlantic cod, Gadus morhua (Skjæraasen et al. 2006), and Chinook salmon, Oncorhynchus tshawytscha (Xiong and Hew 1991). The influence of photoperiods on GnRH production has long been studied and this GnRH will affect the production of $\mathrm{GtH}$, which play a role in fish reproduction (Prayogo, et al. 2012). This effect can have an indirect effect through modulation of neuroendocrine factors that 
regulate GtH release or directly at the level of transcription of the GtH gene. Several studies have shown a link between photoperiods and GtH gene expression in fish (Martins et al. 2015).

The majority of studies were conducted on temperatezone fishes in which photoperiod strictly differ between seasons. Studies on the influence of photoperiod on tropical fishes are still limited. Gouramy (Osphronemu Gouramy Lacepède, 1801), in tropic condition with longer photoperiods 18L:6D, significantly decreased melatonin level and increased gene expression vitellogenin (Prayogo et al. 2018). However, in that study, it was still not clear whether long photoperiods would increase gene expression of $\mathrm{GtH}$ and alter steroidogenesis activity in gouramy or not.

Gouramy (Osphronemus gourami, Lacepède, 1801) is one of the local freshwater fish species with very potential for propagation by fish farmers, especially in the area around Banyumas District, Central Java, Indonesia. Gourami has high economic value, is easily cultivated, and is favored by consumers in Indonesia. Many studies were conducted for increasing and maintaining fish production in Indonesia (Prayogo et al 2012; Prayogo et al 2016a; Prayogo et al 2016b; Prayogo at al. 2018). Osphronemous Gouramy is a synchronous batch spawner fish (Prayogo et al. 2012), which is capable of spawning several times during the peak of the spawning period. Osphronemous gouramy has been adapted to a photoperiod of 12L: 12D to 14L: 10D. The present study examined the effect of different photoperiods on gene expression of FSH and $\mathrm{LH}$ of the gouramy. We also identified FSH and LH genes in the gourami for the first time. This study will inform photoperiods effect on increasing gouramy reproduction.

\section{MATERIALS AND METHODS}

\section{Animals}

I44 sexually mature female and male gouramy weighing of $200 \mathrm{~g}$ in average were maintained at Laboratory of Fisheries and Marine, Jenderal Soedirman University. They were induced to spawn using ovaprim 0,5 $\mathrm{ml} / \mathrm{kg}$ body weight. The day of spawning was designated as day zero post-spawning periods. The post-spawned females were divided into 4 groups. Each group consisted of 4 aquaria with 9 fish/50 L water.

In this study, three types of photoperiods namely 14L:10D (Control), 18L:6D (long Photoperiods), and 6L:18D (short photoperiods) and control have been tested toward concentration of FSH and LH gene expression. The aquaria were covered with light-proof black polybag. The light source provided from 25 Watt (Phillips) bulb regulated by automatic timers 24 hours cycles which were placed at the top of each aquarium. In photoperiod of 14L:10D, light was turned on from 06.00 am until 08.00 $\mathrm{pm}$, and in 18L:6D light was turned on from 06.00 am until $12.00 \mathrm{pm}$, and in $6 \mathrm{~L}: 18 \mathrm{D}$ light was turned on since 06.00 am until 12.00 am local time. Then, the fish were reared for
8 weeks at the laboratory of Aquaculture Department of Marine and Fisheries, University of Jenderal Soedirman.

During the research, fish were fed on commercial pellets (protein $37 \%$ and fat $10 \%$ ) as much as $3 \%$ of total body weight daily. The water was siphoned regularly to maintain water quality. The water temperature, dissolved oxygen, $\mathrm{pH}$, and carbon dioxide

\section{Pituitary collection}

Total RNA and genomic DNA were isolated from pituitary. Total of 150 sexually mature O. gouramy weighing of $200 \mathrm{~g}$ on average was purchased from local market in Banyumas Regency, Central Java, Indonesia. Fish brains were removed, snapped frozen, and stored at $150^{\circ} \mathrm{C}$ with liquid nitrogen until RNA and genomic extraction. Isolation, cloning, and sequencing of FSH and LH gene were perfomed in Laboratory of Gene Expression, Nara Institute Science and Technology (NAIST), Japan.

\section{Genomic DNA isolation}

Total genomic DNA was extracted from pituitary using total DNA kit extraction (geneaid biotech, Taiwan), . The integrity of the DNAs was verified in a denaturing agarose gel, stained with ethidium bromide.

\section{RNA isolation and DNAse treatment}

For total RNA isolation, Sepasol R-RNA super-1 reagent (Takara, Otsu, Japan) was used to extract the brain, (Prayogo et al. 2018). The integrity of RNA were check using denatured agarose gel, stained with ethidium bromide. The RNA samples were treated with DNAse free RNAse (Takara) for removed the DNA. The quality and concentrations of total RNA were determined by agarose gel electrophoresis and optical density reading at $260 \mathrm{~nm}$ and $280 \mathrm{~nm}$, and the RNA was aliquoted in batches and frozen at $-70^{\circ} \mathrm{C}$.

\section{RT-PCR}

Reverse Transcriptase PCR was performed with cDNA synthesis kit (Takara, Otsu, Japan). Total mRNA samples $(1 \mu \mathrm{L})$ reverse using 6 mers (sequence pd $(\mathrm{N}) 6,50 \mu \mathrm{M}$ ) primers and prime script R-tase with manufacture instruction.

\section{cDNA amplification}

FSH and LH primers were designed from Trichogaster trichpterus cDNA. It was used to align sequence to identify the conserved region in open reading frame (ORF) region. The primer to amplify the FSH and LH gene were designed using primer 3 software (Table 1).

Thermal cycler (Robocycler, Stratagene, United States) was used to conduct 35 cycles of PCR for gouramy FSH and LH. Thermal cycler was used according to the following cycle, $95^{\circ} \mathrm{C}$ for $2 \mathrm{~min}, 35$ cycles to $95^{\circ} \mathrm{C}$ for $30 \mathrm{~s}$, $55^{\circ} \mathrm{C}$ for $30 \mathrm{~s}, 72^{\circ} \mathrm{C}$ for $60 \mathrm{~s}$, followed by a 5 min extension at $72^{\circ} \mathrm{C}$. In post-amplification, the PCR products were separated on a $1.5 \%$ agarose gel and stained with ethidium bromide electrophoretically. 
Table 1. The primers used to amplify the GtH genes and their PCR product

\begin{tabular}{|c|c|c|c|}
\hline Name/primer code & DNA sequence (primer) & Tm & PCR product \\
\hline Forward G1 (F1) & GTCTGTACAGATGTTTAGAG & 50.45 & $483 \mathrm{bp}$ \\
\hline Reverse G1 (R1) & CGTGGGATGAATGATGAGAG & 55.7 & \\
\hline Forward G2 (F2) & CTGGCTAACCTGCCGCTGAC & 65.47 & $509 \mathrm{bp}$ \\
\hline Reverse G2 (R2) & GCTTTTGGTTTGCTGTGCAG & 61.90 & \\
\hline Forward G1 Real Time (F2) & TCCCCGAGTTCATCTACACC & 62.81 & $178 \mathrm{bp}$ \\
\hline Reverse G1 Real Time (R2) & TCACAGTTTCTGGCAACAGG & 62.83 & \\
\hline Forward GIIReal Time (F3) & TCTCCAAGGACCCAATCATC & 59.23 & $218 \mathrm{bp}$ \\
\hline Reverse GII Real Time (F3) & CATGCAGAAGTCTGGCTGAA & 60.34 & \\
\hline Forward Actin (FA) & GAGCTATGAGCTCCCTGA CGG & 58.3 & $53 \mathrm{bp}$ \\
\hline Reverse Actin (RA) & AAACGCTCATTGCCAATG GT & 55.6 & \\
\hline
\end{tabular}

\section{Cloning and sequencing of PCR products}

Amplified PCR products separated by agarose gel electrophoresis and DNA gel extraction procedure was used to purify the incised gels. The desired DNA fragments from mRNA FSH, and mRNA LH were subcloned into T vector (10 ng) (Takara) and ligated with T4 ligase. The plasmid was transfected into $E$. coli and spread into LB medium. The positive recombinant colonies screened using ampicillin. Positive colonies were purifying with miniscale plasmid preparation for sequencing. Fragments DNA sequences were determined using the Big Dye version 3.1 sequencing method with specific primers (Table 1). The data were automatically collected on the ABI PRISM 3100 Genetic Analyzer (PE Applied Bio-systems).

\section{Sequence analysis}

FSH and LH gouramy were checked by searching cDNA sequences using BLASTN searches (http://www.ncbi.nlm.nih.gov/BLAST/) performed with default setting, non-redundant GenBank database nucleotide sequences.

\section{Phylogenetic analysis}

Gouramy cDNA FSH, and LH genes were compared to cDNA FSH, and LH sequences from ten fish species, retrieved from NCBI GenBank. Relationship in GtH genes was generated with MULTALIN, and Treeview version 1.5.2 was used to bring about scoring method percent and the unrooted tree.

\section{Quantitative Real-Time analysis}

The primers were designed based on FSH and LH (gene bank submission number : 2321705) using the Primer 3.0 software. Gouramy actin was used as endogenous control, and were used to normalize variations in RNA (table. 1). After optimization, PCR reactions were performed in a 10 $\mu \mathrm{L}$ volume containing $2 \mu \mathrm{L}$ cDNA, $5 \mu \mathrm{L}$ SYBR mix (Applied Biosystem, Massachusetts, USA), $0.3 \mu \mathrm{L}$ forward primer, $0.3 \mu \mathrm{L}$ reverse primer, and $2.4 \mu \mathrm{L}$ of double distilled water (DDW) using the following condition: $95^{\circ} \mathrm{C}$ for $45 \mathrm{~s},\left(45\right.$ cycles of $95^{\circ} \mathrm{C}$ for $15 \mathrm{~s}$ and $60^{\circ} \mathrm{C}$ for $\left.1 \mathrm{~min}\right)$, then $95^{\circ} \mathrm{C}$ for $15 \mathrm{~s}, 60^{\circ} \mathrm{C}$ for $15 \mathrm{~s}$, and $95^{\circ} \mathrm{C}$ for $15 \mathrm{~s} . \Delta \Delta \mathrm{C}_{\mathrm{t}}$ method was used to calculate relative fold change of gene expression. gouramy actin gene was used to normalize the $\mathrm{C}_{\mathrm{t}}$ values of the target genes. Normalized qPCR data were LOG transformed prior to statistical testing.

\section{Data analysis}

SPSS statistical package (version 10.0; SPSS Inc., Chicago, IL, USA) was used to analyze the Real-Time data. Variance one-way analysis followed by Tukey's post hoc test was used to test for significant differences in the data $(p \leq 0.05)$. The values are expressed as the means \pm standard error (SE).

\section{RESULTS AND DISCUSSION}

\section{FSH and LH genes in gouramy}

Gouramy FSH and LH genes were successfully amplified from the cDNA. The agarose gel electrophoresis of the cDNA FSH showed a specific band, approximately 483 bp (fig. 1). The corresponding cDNA sequences were called FSH. The cDNA sequences were checked with BLAST and we found there wasn't 100\% identity with another gene FSH. The nucleotide sequence identity of FSH cDNAs was $90 \%$ with three spot gouramy (Trichogaster trichopterus), 82\% with striped beakfish (Oplegnathus fasciatus), $81 \%$ with Nile perch (Lates niloticus), and $78 \%$ with climbing perch (Anabas testudineus).

Gouramy LH genes were successfully amplified from the cDNA. The agarose gel electrophoresis of the cDNA also showed a specific band, approximately 509 bp for LH (Figure 2), which was called LH. The cDNA sequences were checked with BLAST and we found there wasn't $100 \%$ identity with another gene LH. The nucleotide sequence identity of LH cDNAs was $90 \%$ with three spot gouramy (Trichogaster trichopterus), 87\% with climbing perch (Anabas testudineus), 85\% with grouper (Epinephelus akaara), and 83\% with Nile perch (Lates niloticus) 


\begin{abstract}
GTCTGTACAGATGTTTAGAGAGTAACAGGCACAACCTGCAGCAGAGGTTCAACGAGACAACAGAGATTTA CAGGCGTCTGTGCTGCACCCAAAGGATGAAGCTGGTTGTCATGGCAGCAGTGTTGGCAGTGGCGGGGGTG GGATAGGGTTGCCGCTTCGGCTGTCATCTAACCAACTTCAGCTTCCCCGTAGACAGCTGTGGCATCCCCG AGTTCATCTACACCACCATATGCGCAGGTCATTGCTACCACGAGGATCCAGTCTACATCGGCCACGATGA CTGGGTTGAACAGAAAATCTGTAACGGGGACTGGACCTACGAAGTAAAACACCTACAAGGATGTCCGGTG GCTGTCACGTACCCTGTTGCCAGAAACTGTGAGTGTACTGCTTGTAATGCAGGAAAGACATACTGTGGTC ACTTTCATGGATACATACCCAGCTGTCTGTGATTTCTAAGGCTCTCATCATTCATCCCACGTT
\end{abstract}

Figure 1. LSH sequences in gouramy (Osphronemous gouramy)

\begin{abstract}
CTGGCTAACCTGCCGCTGACACTAAAGAGGATGATGACTGTATAAATAAGCAAAGTGTTTGTCCTAATGA AGTTAAACCTCTTTCTGGGAGCTTCATCTTCCATTTGGTCTGTGGCTCCAGCAGCCTGCCAGCTGCCACG GTGTCAGCTCATCAACCAGACTGTCTCTCTGGAGAAGGAAGGCTGCCCCAGGTGTCACGCAGTGGAAACG ACAATCTGCAGTGGCCACTGCCTCTCCAAGGACCCAATCATCAAGATACCGTTCAGCAATGTGTACCAGC ATGTCTGCACATACCGGGATTTGTTCTATAAGACATTTGAGTTTCCTCCCTGTCCTCCTGGTGTGGACCC AGTCGTCACCTACCCTGTGGCTCTGAGCTGCCACTGCAGCCGTTGTGTCATGGACACATCCGATTGCACC TTCGTGAGTCTTCAGCCAGACTTCTGCATGAATGACATACCTTTCTACTACTTGTCTGATGAAATAGCTG CACAGCAAACCAAAAGCAA
\end{abstract}

Figure 2. LH sequences in gouramy (Osphronemous gouramy)
The high similarity between Gouramy FSH and LH cDNA with another fish can be seen as the distance at the phylogenetic tree (Figures 3 and 4). The greatest differences within the preprohormone are within the GAP coding sequences. The striking contrast between conservation of the GtH coding sequence and lack thereof in the GAP coding sequence is evidence of differential selective pressure within the gene. This is evident in cases where the identity and similarity of GtH and GAP coding sequences have been compared for cDNA of different GtH genes within a species.

\section{Phylogenetic analyses}

The FSH and LH genes were analyzed using phylogenetic analyses. Genetic distances (measured as substitutions per site) showed moderate low values, and the topology was well supported by strong bootstrap values. As expected, FSH genes in gouramy were included within a sub-cluster of the three spot gouramy (Trichogaster trichopterus), Nile perch (Lates niloticus) and largemouth bass (Micropterus salmoides) with high bootstrap values and separated from carp (Ctenopharyngodon idella) and zebrafish (Danio rerio) (Figure 3).

The LH genes in gouramy were separated from other sub-cluster of carp (Ctenopharyngodon idella) and zebrafish (Danio rerio), but was in the same group with tilapia (Oreochromis niloticus), with grouper (Epinephelus akaara), and with Nile perch (Lates niloticus) with high bootstrap values (Figure 4).

\section{Expression of GtH mRNA under photoperiod manipulations}

In gouramy, relative FSH mRNA expression levels in eight weeks were 1.00-6.42 (Figure 4). The highest FSH mRNA expression (6.42) was observed in LP group in eight weeks significantly different $(\mathrm{P}<0.05)$. mRNA expression for 18L:6D group increased with post-spawning periods $(\mathrm{P}<0.05)$. The FSH mRNA expression for other treatment photoperiods in second weeks and fourth weeks was non-significantly different $(\mathrm{P}>0.05)$, but in six weeks and eight weeks, long photoperiods (LP) had higher gene FSH than short photoperiods (SP) and control $(\mathrm{P}<0.05)$. The relative LH mRNA expression level in eight weeks was 6.98-14.71 (Figure 5). The highest LH mRNA expression (14.71) was observed in LP group in eight weeks, which was significantly different $(\mathrm{P}<0.05)$. mRNA expression for 18L:6D (LP) group increased with treatment periods $(\mathrm{P}<0.05)$. The LH mRNA expression for other treatment photoperiods in second weeks and fourth weeks was non significantly different $(\mathrm{P}>0.05)$, but in six weeks and eight weeks, long photoperiods (LP) had higher gene LH than short photoperiods (SP) and control $(\mathrm{P}<0.05)$.

This paper reports for the first time the clone of differing cDNAs encoding the FSH and LH from the pituitary tissues of gouramy. The nucleotide sequence identity of FSH cDNAs was similar to another variant of FSH. BLAST result showed $90 \%$ with three spot gouramy (Trichogaster trichopterus), 82\% with striped beakfish (Oplegnathus fasciatus), $81 \%$ with Nile perch (Lates niloticus), and 78\% with climbing perch (Anabas testudineus) (Figure 7). The same pattern was also reported in $\mathrm{LH}$, The nucleotide sequence identity of LH cDNAs was also very similar with another variant of $\mathrm{LH}$, in which BLAST result showed that $90 \%$ with three spot gouramy (Trichogaster trichopterus), $87 \%$ with climbing perch (Anabas testudineus), 85\% with grouper (Epinephelus akaara), and $83 \%$ with nile perch (Lates niloticus) (Figure $8)$. 


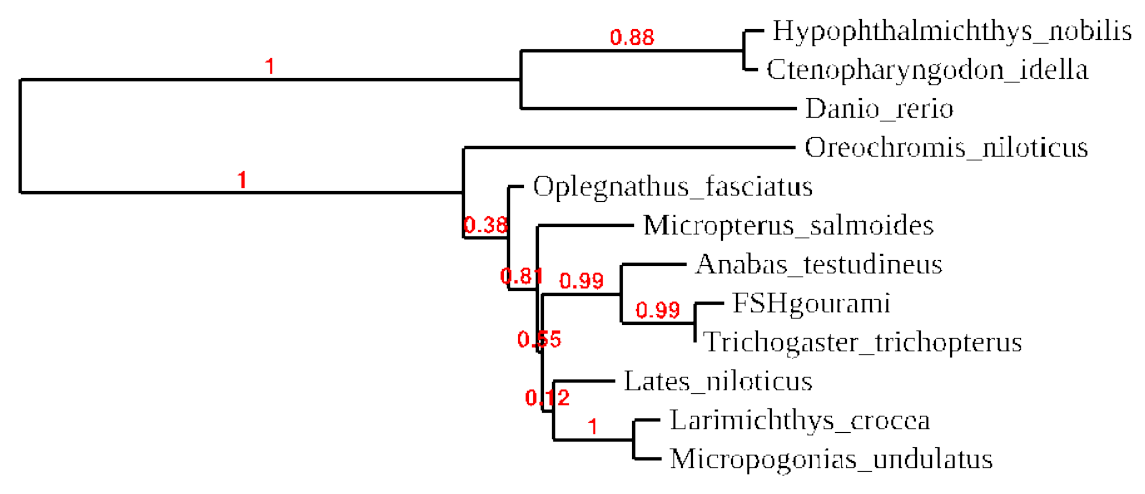

0.2

Figure 3. Phylogenetic relationship of precursors derived from known nucleotide encodes follicle-stimulating hormone (FSH). The relationship was generated with CLUSTAL W and the unrooted tree was generated using Treeview version 1.5.2. The scale bar represents the estimated evolutionary distance as 0.1 amino acid substitutions per site

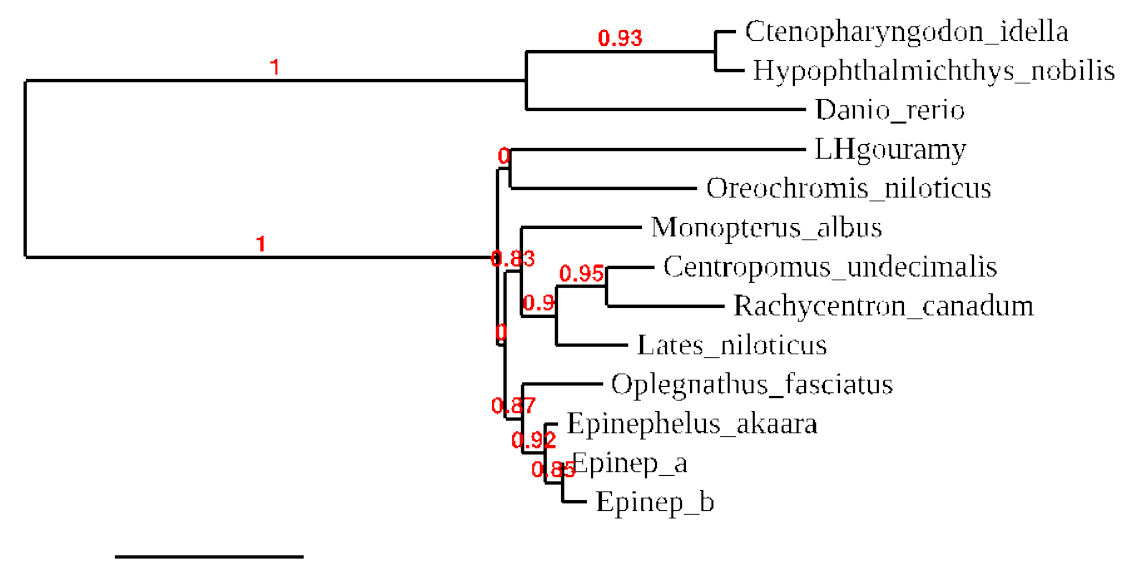

0.1

Figure 4. Phylogenetic relationship of precursors derived from known nucleotide encodes luteinizing hormone (LH). The relationship was generated with CLUSTAL W and the unrooted tree was generated using Treeview version 1.5.2. The scale bar represents the estimated evolutionary distance as 0.1 amino acid substitutions per site

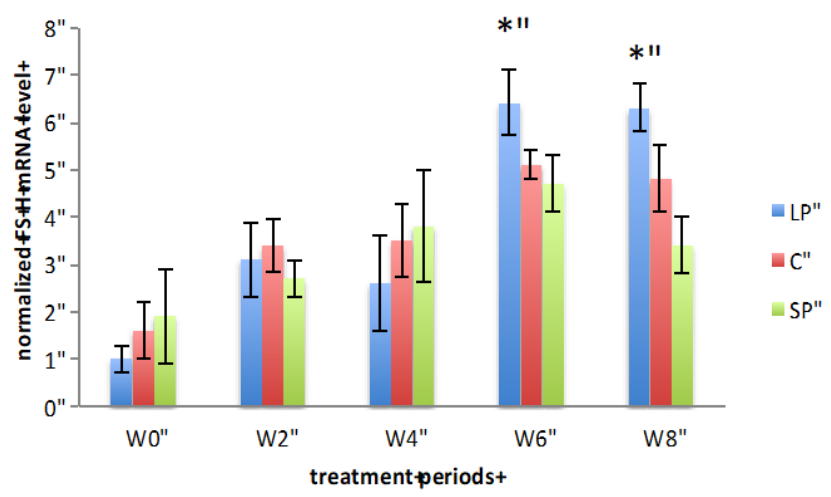

Figure 5. FSH gene expression of gouramy kept under different photoperiod for 8 weeks. $\mathrm{C}=14 \mathrm{~L}$ : $10 \mathrm{D}$ (control), $\mathrm{SP}=8 \mathrm{~L}: 16 \mathrm{D}$ (short photoperiods) and $\mathrm{LP}=18 \mathrm{~L}$ : 6D (long photoperiods),). (* symbol : Significantly different, ANOVA were analyzed every 2 weeks)

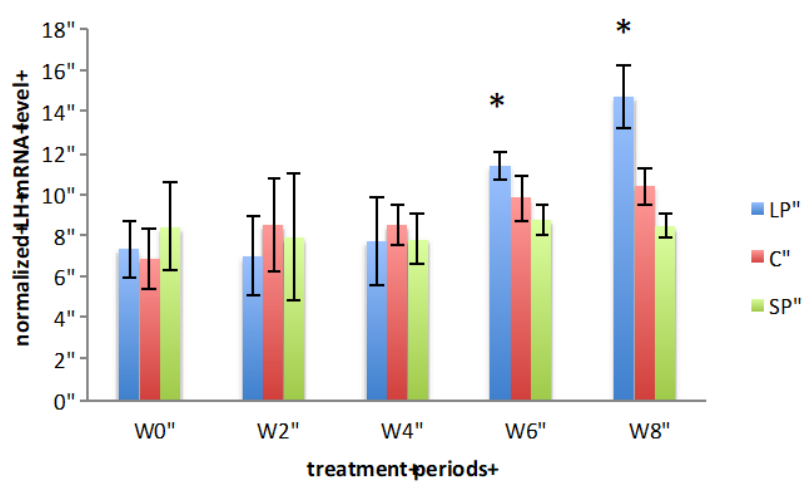

Figure 6. LH gene expression of gourami was kept under different photoperiod for 8 weeks. $\mathrm{C}=14 \mathrm{~L}$ : $10 \mathrm{D}$ (control), $\mathrm{SP}=8 \mathrm{~L}$ : 16D (short photoperiods) and LP=18L:6D (long photoperiods), ). (* symbol : Significantly different, ANOVA were analyzed every 2 weeks) 


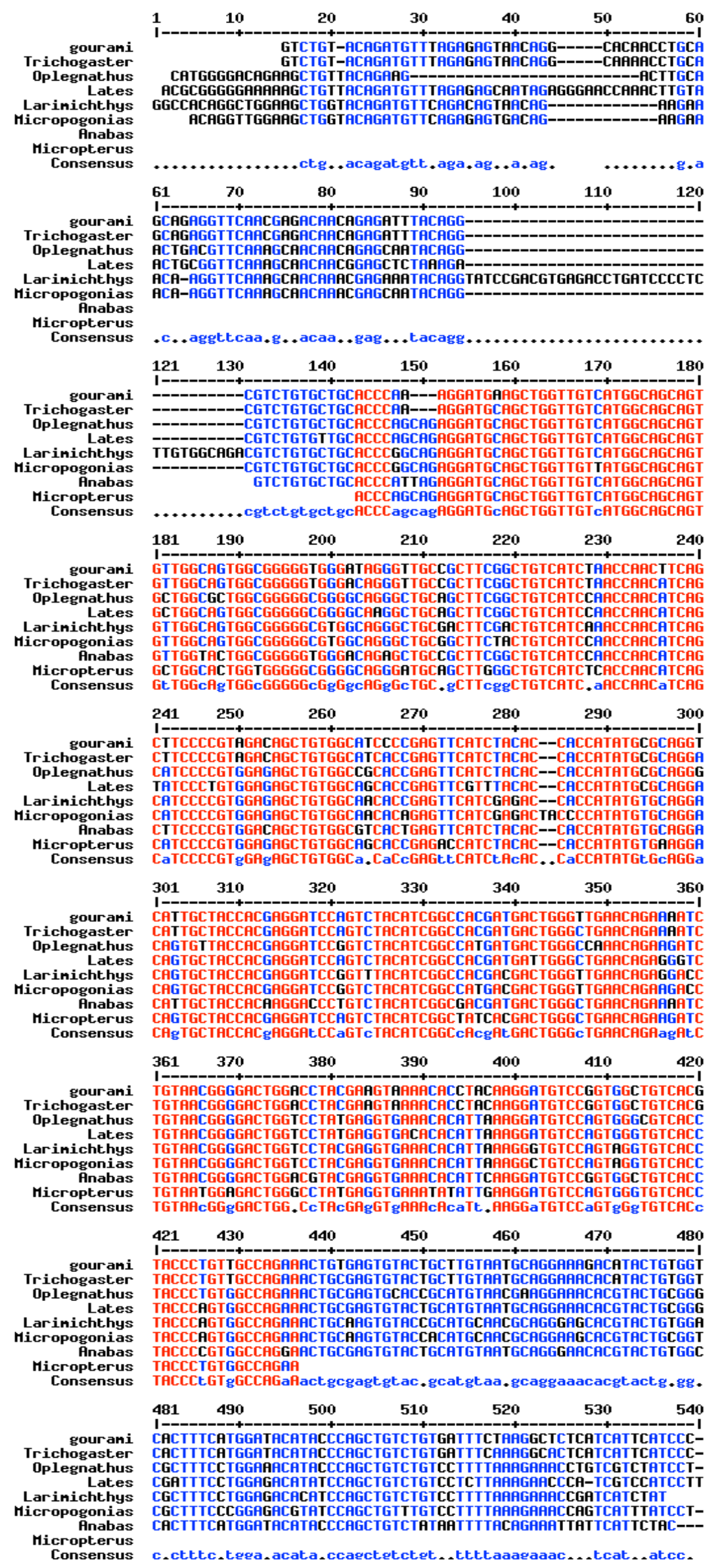

Figure 7. Alignment of FSH gene in gourami with another teleost. (red color: conserved area, blue and black color: not conserved area) 


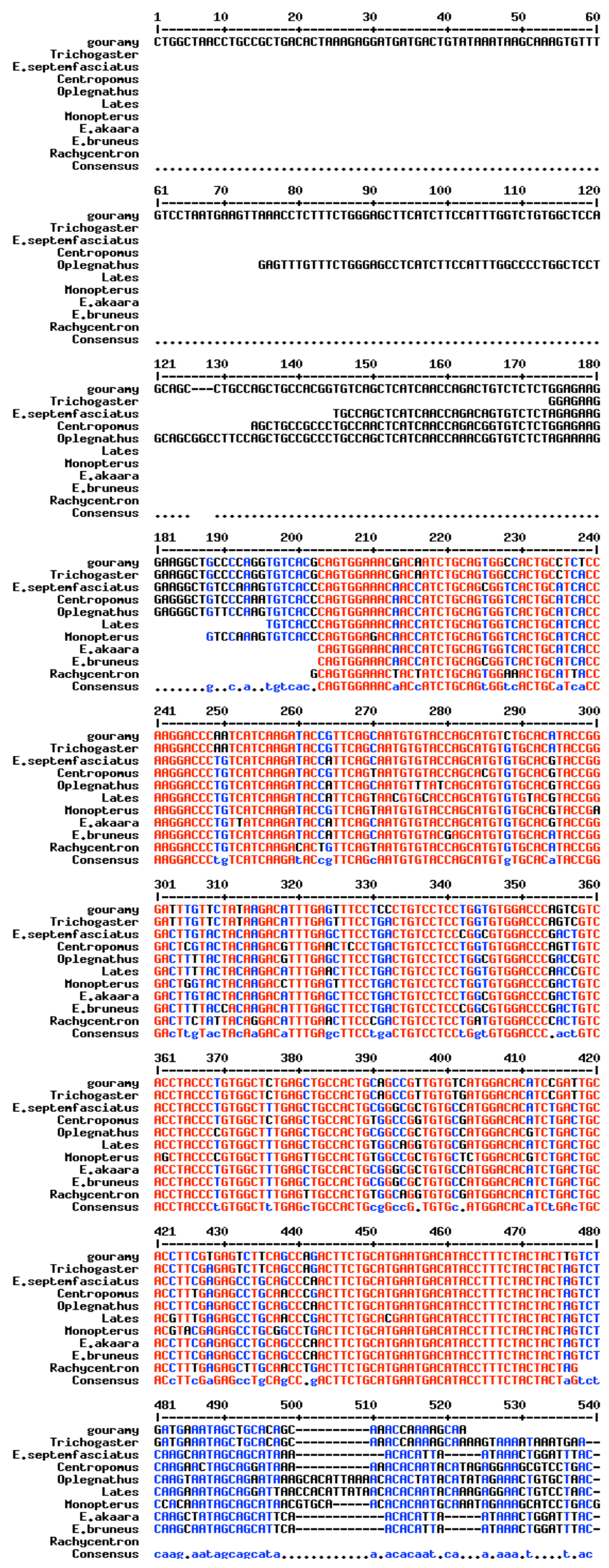

Figure 8. Alignment of LH gene in gouramy with another teleost. (red color: conserved area, blue and black color: not conserved area) 
The present study provides new evolutionary information on FSH and LH gene family in the pituitary. The FSH and LH in gouramy were grouped together with another teleost in the phylogenetic tree, that was suggesr that a common ancestor. The Phylogenetic analysis shows that GtH gouramy had closed character with three spot gouramy (Trichogaster trichopterus), striped beakfish (Oplegnathus fasciatus), Nile perch (Lates niloticus), and $78 \%$ with climbing perch (Anabas testudineus) (Figures 3 and 4), indicating that they also have some same features and functionality. Furthermore, FSH and LH gouramy were very similar to three spots gouramy assuming that gouramy also had two subunits name alpha and beta.

Previous studies in teleost showed that extended photoperiod decreased melatonin and increased gene expression of cGnRH-II, gene expression of $\mathrm{sGnRH}$ and estradiol level (Prayogo et al. 2012). Longer photoperiods lead to decreased melatonin production and have an impact on increasing $\mathrm{GnRH}$ and $\mathrm{GtH}$ production (Bromage et al. 2001; Bayarri et al. 2004; Miranda et al. 2008). This study confirms previous results from fisheries laboratory showing an increase in FSH and $\mathrm{LH}$ genes levels during photoperiod manipulations in gouramy. In addition, it can be reported that for the first time, changes in the gene expression levels of FSH and LH genes in correlation with photoperiod manipulations. Although awareness had come to the researcher that mRNA levels do not always match with protein levels and/or the physiological effects of the protein products, the regulation of mRNA levels provides an indication of the activity of a particular peptide neuronal system.

This study denoted that the increase of FSH and LH levels was equivalent to the long photoperiod increase. This was proved that photoperiod exerts its role on reproduction through hypothalamus-pituitary-gonad that integrates and conveys input from external and internal cues to the pituitary organs (Cassone 1998; Juell and Fosseidengen 2004; Minniti et al. 2007). Photoperiods regulated melatonin production and melatonin mediated cyclical regulation of GnRH mRNA expression involving the protein kinase $\mathrm{C}$ and the extracellular signal-regulated kinase 1 and 2 pathways. Melatonin regulating act through membrane receptors to trigger the protein kinase $\mathrm{C}$ pathway and 12-O- tetradecanoyl phorbol-13-acetate (TPA), a modulator of this pathway, has been shown to suppress GnRH gene expression through the promoter (Qingbo et al. 2005; Prayogo et al. 2012). GnRH binds to $\mathrm{GnRH}$ receptor and active $\mathrm{G}$ protein-mediated phosphorylation to protein kinase $\mathrm{C}$ and synthesis Gonadotrophin (FSH and $\mathrm{LH}$ ). $\mathrm{LH}$ secreted into the blood vessel, to the receptor in theca cell to activate $\mathrm{G}$ protein and adenylate cyclase to phosphorylation cAMP and activation of staR protein. staR protein regulated cholesterol (Volkoff and Peter 1999). On the contrary, short photoperiod stimulated melatonin production and suppressed the hypothalamus-pituitary-gonad axis (Cassone 1998). Therefore, increasing photoperiod should, in theory, increase the reproductive activities (Prayogo et al. 2012).

In summary, the present work has reported for the first time the cDNA sequence of $\mathrm{GtH}$ genes variants in a gouramy, the phylogenetic results presented in this work support the idea that all GtH genes share the same basic structure. It means that FSH and LH in gouramy are very conservative assuming that it had the same function with another teleost. Photoperiod affected regulation of gene expression of FSH and LH in the gouramy. More extended photoperiod will increase gene expression of $\mathrm{FSH}$ and $\mathrm{LH}$, via $H P G$ axis.

\section{REFERENCES}

Shin HS, Song JA, Choi JY, Kim NN, Choi YJ, Sung SN, Park MS, Min BH, Choi CY. 2014. Effects of various photoperiods on Kisspeptin and reproductive hormones in the goldfish, Carassius auratus. Animal Cells Sys 18 (2): 109-118.

Martins RS, Gomez A, Zanuy S, Carrillo M, Canário AV. 2015. Photoperiodic modulation of circadian clock and reproductive axis gene expression in the pre-pubertal European Sea Bass Brain. PLoS One 10 (12): e0144158. DOI: 10.1371/journal.pone.0144158.

Minniti F, Maisano M, Giannito A, Mauceri A, Sasuolo F. 2007. GtH I and $\mathrm{GtH}$ II in the pituitary gland of swordfish (Xiphias gladius 1.). Ital J Zool 76: 269-278.

Miranda LA, Strussmann CA, Somoza GM. 2008. Effects of light and temperature conditions on the expression of GnRH and $\mathrm{GtH}$ genes and levels of plasma steroids in Odontesthes bonariensis females. Fish Physiol Biochem 35: 101-108.

Moniruzzaman M, Maitra SK. 2012. Influence of altered photoperiods on serum melatonin and its receptors (MT1 and MT2) in the brain, retina, and ovary in carp Catla catla. Chronobiol Intl 29 (2): 175-188.

Prayogo NA, Wijayanti GE, Murwantoko, Kawaichi M, Astuti P. 2012. Effect of photoperiods on melatonin levels, estradiols level and the expression of cgnrh-ii and sgnrh genes, in hard-lipped barb (Osteochilus hasselti C.V.). J Global Vet 8 (6): 591-597.

Prayogo NA, Wijayanti GE, Sulistyo I, Sukardi P. 2016a. Cloning and expression cGnRH-II and sGnRH genes in hard-lipped barb (Osteochilus hasselti C.V.). Biodiversitas 17 (29): 523-530.

Prayogo NA, Siregar AS, Sukardi P. 2016b. The disruptive effect mercury chloride $(\mathrm{HgCl})$ on gene expression of cGnRH-II sGnRH, and estradiol level in silver shark minnow (Osteochillus hasseltii C.V.). Turk J Fish Aquat Sci 16 (2): 1003-1009

Prayogo NA, Siregar AS, Sukardi P, Bessho Y. 2018. Molecular cloning of the vitellogenin gene in the hard-lipped barb (Osteochillus hasseltii C.V) and photoperiod's effects on gene expression. Biotropia J 25 (3): 211-233.

Qingbo T, Mazur M, and Mellon PL. 2005. The protein kinase c pathway acts through multiple transcription factors to repress gonadotropinreleasing hormone gene expression in hypothalamic gt1-7 neuronal cells. Mol Endocrinol 19 (11): 2769-2779.

Lapthorn AJ, Harris DC, Littlejohn A, Lustbader JW, Canfield RE, Machin KJ. 1994. Crystal structure of human chorionic gonadotropin. Nature 369: 455-461.

Skjæraasen JE, Nilsen T, Kjesbu OS. 2006. Timing and determination of potential fecundity in Atlantic cod (Gadus morhua). Fish Aquat Sci 63: 310-320.

Siregar AS, Prayogo NA. 2018. The disruptive effect of mercury chloride $(\mathrm{HgCl})$ on gene expression of gonadotrophin hormones and testosterone level in male silver shark minnow (Osteochilus hasseltii C.V.) (Teleostei: Cyprinidae). Eur Zool J 84 (1): 436-443

Ulloa AA, Timossi C, Damian MP. 1999. Role of glycosylation in function of follicle-stimulating hormone. Endocrine 11 (3): 205-15.

Veras GC, Murgas LDS, Rosa PV, Zangeronimo MG, Ferreira MSS, Leon JAS. 2013. Effect of photoperiod on locomotor activity, growth, feed efficiency and gonadal development of Nile tilapia. Revista Brasileira de Zootecnia 42 (12): 844-849.

Xiong F, Hew CL. 1991. Chinook salmon gonadotropin II ß-subunit gene encodes multiple messenger ribonucleic acids. Can J Zool 69: 2572-2578.

Zhang RS, Zhang X, Zhu Y, Zhou B, Wu X. 2015. Molecular characterization of the Chinese alligator follicle-stimulating hormone $\beta$ subunit $(\mathrm{FSH} \beta)$ and its expression during the female reproductive cycle. Comp Biochem Physiol 183: 49-57. 